\title{
Ön İşlem Uygulanmış Alg Biyokütlesinin Mikrobiyal Yakıt Hücresinde Elektrik Üretim Performansının Araştırılması
}

\author{
Muhammed Fatih HASAR ${ }^{1}$, Ergin TAŞKAN ${ }^{* *}$ \\ ${ }^{1}$ Çevre Mühendisliği Bölümü, Mühendislik Fakültesi, Fırat Üniversitesi, Elâzığ, Türkiye \\ ${ }^{2}$ Çevre Mühendisliği Bölümü, Mühendislik Fakültesi, Fırat Üniversitesi, Elâzı̆̆, Türkiye \\ ${ }^{1}$ hasar.mf@gmail.com, ${ }^{* 2}$ etaskan@ firat.edu.tr
}

(Geliş/Received: 11/04/2021;

Kabul/Accepted: 03/06/2021)

Öz: Alg biyokütlesi yüksek organik içeriğinden dolayı mikrobiyal yakıt hücreleri (MYH) için eşsiz substrat kaynaklarından biridir. Fakat alg hücre duvarının kompleks yapısı biyolojik parçalanabilirliğini önemli ölçüde kısıtlamaktadır. Bu çalışmada farklı konsantrasyonlarda (5-30 ml/L aralığında) hidrojen peroksit $\left(\mathrm{H}_{2} \mathrm{O}_{2}\right)$ kullanılarak alg biyokütlesine ön işlem uygulanmış ve MYH sisteminde elektrik üretim performansı araştırılmıştır. MYH'de maksimum güç yoğunluğu $\left(244.64 \mathrm{~mW} / \mathrm{m}^{2}\right) 25 \mathrm{ml} / \mathrm{L}$ $\mathrm{H}_{2} \mathrm{O}_{2}$ konsantrasyonunda ön işlem uygulanmış alg biyokütlesi ile elde edilmiştir. Elde edilen maksimum güç miktarı kontrol reaktörüne $\left(41.16 \mathrm{~mW} / \mathrm{m}^{2}\right)$ kıyasla yaklaşık olarak altı kat daha yüksektir. Moleküler analizler, ön işlem uygulanmış alg biyokütlesinin kullanıldığı MYH reaktöründe (MYH-A) b-proteobacteria grubuna ait bakteriyel türlerin oranının kontrol reaktörüne (MYH-K) kıyasla \%10 arttı̆̆ını göstermiştir. Ayrıca döngüsel voltametri (CV) sonuçları, MYH-A reaktörlerindeki anot biyofilminin MYH-K reaktörünün anot biofilmine kıyasla daha yüksek bir elektroaktiviteye sahip olduğunu göstermiştir. Çalışma sonuçları, $\mathrm{H}_{2} \mathrm{O}_{2}$ 'nin alg biyokütlesinin biyolojik olarak parçalanmasını desteklemek ve MYH'nin elektrik üretim performansını iyileştirmek için etkili bir ön işlem yöntemi olduğunu göstermiştir.

Anahtar kelimeler: Mikrobiyal yakıt hücresi, alg biyokütlesi, ön işlem, $\mathrm{H}_{2} \mathrm{O}_{2}$, mikrobiyal çeşitlilik.

\section{Investigation of Electricity Generation Performance of Pretreated Algal Biomass in Microbial Fuel Cell}

\begin{abstract}
Algal biomass is one of the unique substrate sources for microbial fuel cells (MFCs) because of its high organic content. However, the complex cell wall of algal cells substantially limits biodegradability. In this study, the electricity generation performance of the algal biomass, pretreated using hydrogen peroxide at different concentrations (between 5-30 $\mathrm{mg} / \mathrm{L}$ ), was investigated in MFC. The MFC produced the maximum power density $\left(244.64 \mathrm{~mW} / \mathrm{m}^{2}\right)$ with algal biomass pretreated with $\mathrm{H}_{2} \mathrm{O}_{2}$ at the concentration of $25 \mathrm{ml} / \mathrm{L}$. The obtained maximum power density is six times higher than the power density $\left(41.16 \mathrm{~mW} / \mathrm{m}^{2}\right)$ of the control MFC. The molecular analyses showed that the relative ratio of bacterial species belongs to the b-proteobacteria class in the main MFC (MFC-A) is 10\% higher compared to the relative ratio in control MFC (MFC$\mathrm{K})$. Additionally, cyclic voltammetry (CV) results showed that the anode biofilm in MFC-A has higher bioelectroactivity than anode biofilm of MFC-K. The results showed that $\mathrm{H}_{2} \mathrm{O}_{2}$ is an effective pretreatment method to promote the biodegradation of algal biomass and improve the electricity generation performance of MFC.
\end{abstract}

Key words: Microbial fuel cell, algae biomass, pretreatment, $\mathrm{H}_{2} \mathrm{O}_{2}$, microbial diversity.

\section{Giriş}

Günümüzde, artan enerji ihtiyacı ve yüksek yakıt fiyatları nedeni ile yenilenebilir enerji kaynaklarının kullanımı oldukça önemli hale gelmiştir [1]. Bu nedenle araştırmacılar, sürdürülebilir ve uygun maliyetli enerji üretim teknolojileri üzerine yoğunlaşmışlardır [2, 3]. MYH'ler organik bileşiklerden doğrudan elektrik üretebilme yeteneğine sahip olmalarından dolayı önemli bir yenilenebilir enerji üretim teknolojisidir [4]. Klasik bir MYH, anot bölmesi, katot bölmesi ve bu bölmeleri fiziksel olarak birbirinden ayıran proton değişim membranından (PDM) oluşmaktadır. Anot bölmesinde elektrot yüzeyinde bulunan mikroorganizmalar, organik bileşikleri oksitleyerek elektron $\left(\mathrm{e}^{-}\right)$ve proton $\left(\mathrm{H}^{+}\right)$üretimini gerçekleştirir [5]. Protonlar PDM aracılığ ile elektronlar ise dış direnç vasıtası ile katot bölmesine ulaşır ve burada oksijen ile birleşerek suyu oluştururlar [6]. MYH'leri büyük ölçekte uygulanabilir hale getirmek için araştırmacılar, yeni substrat kaynakları [7], elektrot malzemeleri [8] ve yeni reaktör tasarımlarına odaklanmıştır [9]. MYH’lerde anot bakterileri için substrat kaynağı olarak genellikle sentetik ve evsel kaynaklı atıksular kullanılmasına rağmen son yıllarda alg biyokütlesi gibi organik içeriği yüksek substrat kaynaklarına yönelim artmıştır [10].

\footnotetext{
* Sorumlu yazar: etaskan@ firat.edu.tr. Yazarların ORCID Numarası: ${ }^{1}$ 0000-0002-9496-3697, ${ }^{2}$ 0000-0002-9620-8644
} 
Mikroalgler, yüksek büyüme oranlarına sahip olması [11], $\mathrm{CO}_{2}$ fiksasyonu [12] ve atıksudan nütrient giderimi yapabilme yeteneğinden [13] dolayı yaygın bir kullanım alanına sahiptir. Bu nedenle, dünya genelinde yüksek miktarda alg biyokütlesi üretilmektedir. Alg biyokütlesi yüksek düzeyde protein, lipit, karbonhidrat ve farklı biyomoleküller içermesinden dolayı MYH'lerde anot bakterileri için eşsiz bir substrat kaynağı potansiyeli taşımaktadır. Fakat alg hücrelerinin kompleks hücre duvarına sahip olması, anot bakterileri tarafindan gerçekleştirilen mikrobiyal parçalanmayı ciddi oranda güçleştirmektedir [14]. Bu nedenle, MYH sistemlerinde mikroalgler kullanılarak elektrik üretim performansını arttırmak için ön işlem uygulamaları oldukça önemlidir.

$\mathrm{H}_{2} \mathrm{O}_{2}$ oldukça etkili bir oksitleyici olup katı biyokütlelerin sıvılaştırılmasını artırmakta ve biyodegredasyon sürelerini kısaltmaktadır $[15,16]$. Ön işlem olarak $\mathrm{H}_{2} \mathrm{O}_{2}$ uygulanması durumunda, biyokütlenin disentegrasyonu (parçalanma) daha kolay bir şekilde gerçekleşmekte ve biyokütlenin organik içeriği sıvı faza geçerek sıvılaşma oluşmaktadır. Bu durum aynı zamanda çözünmüş kimyasal oksijen ihtiyacı (KOİ) konsantrasyonunun artması ve biyopolimerlerin serbest kalarak sıvı faza geçmesi şeklinde de ifade edilmektedir [17]. $\mathrm{H}_{2} \mathrm{O}_{2}$ ile ön işlem sırasında oluşan hidroksil radikali (HO), alg ve katı fazlı biyokütlelerin dağılmasını ve dolayısıyla sıvılaşmasını hızlandırmaktadır. HO Radikali, hücre duvarını parçalamakta ve böylece hücresel içeriğin sıvı faza geçişi meydana gelmektedir [18]. Sonuç olarak oksitleyici yardımı ile sıvı faza geçen bu çözünmüş organikler, bakteriler tarafindan kolayca ayrıştırılarak kullanılabilirler. $\mathrm{H}_{2} \mathrm{O}_{2}$ ile ön işlem uygulaması, daha önce birçok farklı biyolojik arıtma proseslerinde kullanılarak sistemin giderim performansı iyileştirilmiştir [19]. Daha önce yapılan bir çalışmada mikrodalga- $\mathrm{H}_{2} \mathrm{O}_{2}$ uygulaması, anaerobik bir çürütme prosesinde ön işlem amacı ile kullanılmıştır. Besleme çamuruna mikrodalga- $\mathrm{H}_{2} \mathrm{O}_{2}$ ön işlemlerinin uygulanmasıyla kontrol reaktörüne kıyasla ana reaktörde hem toplam katı madde miktarında azalma hem de günlük metan üretiminde $\% 18.3$ artış meydana geldiği rapor edilmiștir [20]. Rashid ve ark. [21] tarafından yapılan bir çalışmada, MYH sisteminde substrat kaynağı olarak kullanılmak için Scenedesmus türü alg biyokütlesine sonikasyon ön işlemi uygulanmıştır. Çalışmada $2 \mathrm{dk}$ boyunca $20 \mathrm{KHz}$ 'de sonikasyon ön işlemi uygulanmış ve 1,2 ve $5 \mathrm{~g} / \mathrm{L}$ konsantrasyonunda alg beslemesi ile $0.56,0.85$ ve $1.78 \mathrm{~W} / \mathrm{m}^{2}$ güç yoğunlukları elde edilmiştir [22]. Bu çalışmada alg biyokütlesinin biyolojik ayrıştırılabilirliğini arttırmak amacı ile farklı konsantrasyonlarda $\mathrm{H}_{2} \mathrm{O}_{2}$ ön işlem olarak uygulanmıștır. Ardından alg biyokütleleri MYH sisteminde substrat kaynağı olarak kullanılmış ve elektrik üretim performansları detaylı bir şekilde araştırılmıştır. Ayrıca, $\mathrm{H}_{2} \mathrm{O}_{2}$ ön işleminin anot biyofilminde mikrobiyal komunite üzerindeki etkisi PCR-DGGE yöntemleri ile tespit edilmiştir.

\section{Materyal ve Metot}

\subsection{Alg izolasyonu ve kültürlenmesi}

Çalışmada kullanılan karışık alg türleri Elazığ ili Kehli deresinden (38³5'36.3"N 39²0'23.6"E) alınarak Ashok ve ark. [23] tarafindan verilen prosedüre göre çoğaltılmıştır. Elde edilen karışık alg türleri, $500 \mathrm{ml}$ 'lik silindirik plastik şişelerde Muñoz ve ark. [24] tarafindan verilen besi ortamı kullanılarak oda sıcaklığında ve 2000 lux 1şık yoğunluğunda kültürlenmiştir.

\subsection{MYH kurulumu ve işletimi}

Çalışmada tek bölmeli hava katot MYH reaktörleri kullanılmıştır. Reaktörler pleksiglas malzemeden yapılmış olup anot bölmelerinin etkin çalışma hacmi $10 \mathrm{ml}$ 'dir (Şekil 1). Reaktörlerde anot ve katot elektrotu olarak grafit (FuelCellStore, USA) ve \%5 oranında platin katkılı karbon kâğıt kullanılmıştır. Anot ve katot elektrotları 1000 Q'luk direnç kullanılarak sabitlenmiştir. Ayrıca MYH reaktörlerinde PDM olarak ULTREX CMI-7000 membran ve gaz difüzyon tabakası olarak karbon fiber kâğıt (AvCarb P50T- FuelCellStore, USA) kullanılmıştır. PDM'ler kullanılmadan önce üretici firmanın vermiș olduğu prosedür dikkate alınarak ( $\% 5^{\prime} l i k \mathrm{NaCl}$ içerisinde $\left.12 \mathrm{sa}\right)$ şartlandırılmışıı. MYH'lerin anot bölmeleri Elâzığ ili kentsel atıksu arıtma tesisinin girişinden alınan atıksu ile aşılanmıştır. MYH'ler işletmeye alındıktan sonra besleme yapmak için sabit bir elektrik üretimi elde edilinceye kadar beklenmiş ve sabit elektrik üretiminden sonra kuru ağırlığ 2 gr olacak şekilde toplamda $10 \mathrm{ml}$ hacme sahip alg biyokütlesi reaktöre enjekte edilmiștir. $\mathrm{H}_{2} \mathrm{O}_{2}$ ön ișleminin MYH'deki biyofilm yapısının elektroaktif özelliklerini ve baskın mikrobiyal tür yapısındaki değişimi incelemek amacı ile reaktörlerden biri kontrol reaktörü (MYH-K) olarak işletilmiş ve ön işlem uygulanmayan (ham) alg biyokütlesi ile besleme yapılmıştır. Diğer reaktör ise ana reaktör (MYH-A) olarak işletilmiş ve sırası ile 5, 10, 15, 20, 25 ve $30 \mathrm{ml} / \mathrm{L}$ konsantrasyonlarında $\mathrm{H}_{2} \mathrm{O}_{2}$ ön işlemi uygulanmış alg biyokütleleri ile besleme yapılmıştır. 


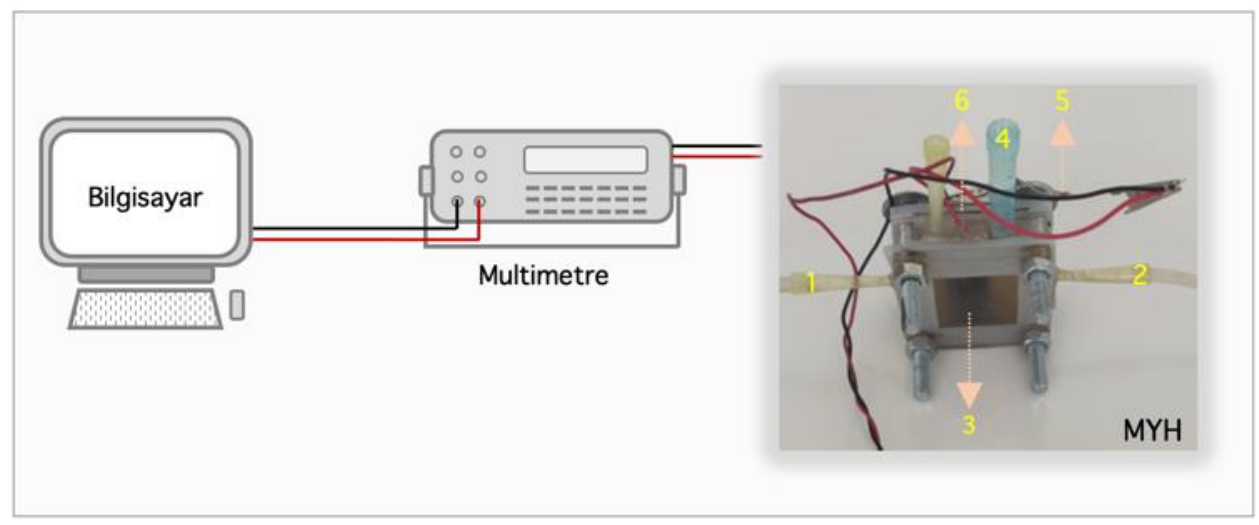

Şekil 1. Çalışmada kullanılan MYH sisteminin şematik görünümü (1: Giriş, 2: Çıkış, 3: Anot elektrotu, 4: Referans elektrot alanı, 5: Dış direnç, 6: Katot elektrotu)

\subsection{Elektrokimyasal analizler}

Elektrokimyasal analizler Gamry Interface 1000 potansiyostat (Gamry, Warminster, PA) cihazı kullanılarak üçlü elektrot sistemi (anot: grafit elektrot, katot: platin katkılı karbon kâğıt ve referans elektrot: gümüş-gümüş klorür $(\mathrm{Ag} / \mathrm{AgCl}))$ ile gerçekleştirilmiştir. Elde edilen veriler bilgisayara kaydedilerek Gamry Framework Data Acquisition yazılımı kullanılarak analiz edilmiştir. Doğrusal taramalı voltametri (LSV) analizi $0.25 \mathrm{mV} / \mathrm{s}$ tarama hızında gerçekleştirilmiştir. CV analizi MYH reaktörlerine işletme süresi sonunda $-1 \mathrm{~V}$ ile $0.75 \mathrm{~V}$ aralığında 5 $\mathrm{mV} / \mathrm{s}$ tarama hızında gerçekleştirilmiştir [25]. MYH reaktörlerinde üretilen akım yoğunluğu $\left(\mathrm{mw} / \mathrm{m}^{2}\right)$ ve güç yoğunluğu $\left(\mathrm{A} / \mathrm{m}^{2}\right)$ değerleri Denklem (1) ve Denklem (2) kullanılarak hesaplanmıştır.

$$
\begin{aligned}
& \text { Akım Yoğunluğu }=\frac{\mathrm{I}}{\text { elektrot yüzey alanı }\left(\mathrm{m}^{2}\right)} \\
& \text { Güç Yoğunluğu }=\frac{\mathrm{I.V}}{\text { elektrot yüzey alanı }\left(\mathrm{m}^{2}\right)} \\
& \text { Burada; } \\
& \text { V: Potansiyel, volt } \\
& \text { I: Akım, amper } \\
& \text { R: Direnç, ohm ifade etmektedir. }
\end{aligned}
$$

\subsection{Moleküler analizler}

MYH reaktörlerinin işletme süresi sonunda anot elektrotu yüzeyinden alınan biyofilm numuneleri $-20^{\circ} \mathrm{C}$ 'de muhafaza edilmiş ve ardından DNA izolasyon işlemi Power soil DNA ekstraksiyon kiti (Qiagen, Hilden, Germany) kullanılarak üretici firmanın vermiş olduğu prosedür kullanılarak gerçekleştirilmiştir. DNA izolasyon işleminden sonra elde edilen saf DNA'lara polimeraz zincir reaksiyonu (PCR) işlemi uygulanarak 16S rRNA genleri çoğaltılmıştır. PCR işlemi GC-BacV3f (5'-CGCCCG CCGCGCGCGGCGGGCGGGGCGGGGGCACGGGGGGCCTACGGGAGGCAG CAG-3') [26] ve 907R (5'CCGTCAATTCMTTTGAGTTT-3') [27] primerleri kullanılarak Tablo 1'de verilen işlem basamakları takip edilerek gerçekleştirilmiştir [28].

Tablo 1. PCR analizinin işlem basamakları

\begin{tabular}{lcc}
\hline İşlem Basamağı & Süre (sn) & Sıcaklık $\left({ }^{\circ} \mathbf{C}\right)$ \\
\hline İlk denatürasyon & 130 & 94 \\
Denatürasyon & 30 & 94 \\
Primer bağlanması & 45 & 56 \\
Uzama & 130 & 72 \\
\hline
\end{tabular}


PCR işleminin başarısını kontrol etmek için PCR ürünleri \%1'lik (w/v) agaroz jel içerisinde $100 \mathrm{~V}$ 'da $20 \mathrm{dk}$ süre ile yürütülmüş ve jel görüntüleme cihazı (Vilber Lournat, Fransa) kullanılarak ilgili genlerin çoğaltılıp çoğaltılmadığı kontrol edilmiştir. Ardından denatüre edici gradient jel elektroforezi (DGGE) analizi ile bakterilere ait her bir DNA'nın denatüre jel içerisinde ayrılması sağlanmıştır. DGGE işlemi INGENYphorU elektroforez sistemi (INGENY ${ }^{\circledR}$, Leiden, Netherlands) kullanılarak gerçekleştirilmiştir. DGGE işleminden sonra elde edilen saf DNA'lar PCR işlemine tabi tutulmuş ve ardından sekans analizi gerçekleştirilerek mevcut türler tanımlanmıştır.

\section{Bulgular ve Tartışma}

\subsection{Elektrik üretim performansı}

\subsubsection{Voltaj üretimi}

Çalışmada $\mathrm{H}_{2} \mathrm{O}_{2}$ ön işleminin MYH'nin elektrik üretim performansı üzerindeki etkisini değerlendirmek amacı ile ham ve $\mathrm{H}_{2} \mathrm{O}_{2}$ ön uygulamasına tabi tutulmuş alg biyokütlesi $\mathrm{MYH}$ reaktörlerine besleme yapılmış ve elektrik üretim performansları değerlendirilmiştir. Her bir besleme için MYH'nin voltaj üretimi izlenmiş ve voltaj değerinde sabitlenmenin görüldüğü noktada işletim süreci durdurulmuştur (yaklaşık $190 \mathrm{dk}$ ). Ön işleme tabi tutulmuş alg biyokütleleri MYH-A reaktörüne düşük konsantrasyondan başlayarak $(5 \mathrm{ml} / \mathrm{L})$ yüksek konsantrasyon değerine $(30 \mathrm{ml} / \mathrm{L})$ doğru beslenme yapılmıştır. MYH-K reaktörüne yapılan ön işleme tabi tutulmamış (kontrol) beslemesi ve MYH-A reaktörüne yapılan ön işleme tabi tutulmuş alg biyokütlesi beslemeleri için üretilen voltaj değerleri Şekil 2'de verilmiştir. Voltaj değerleri incelendiğinde, MYH reaktöründe üretilen voltaj değerinin yaklaşık 180 dk'lık süre boyunca arttığı ve daha sonra sabitlenmeye başladığı gözlemlenmiştir. Bu nedenle MYH'nin voltaj değerleri her bir besleme için 190 dk'lık süre dikkate alınarak kıyaslanmıştır.

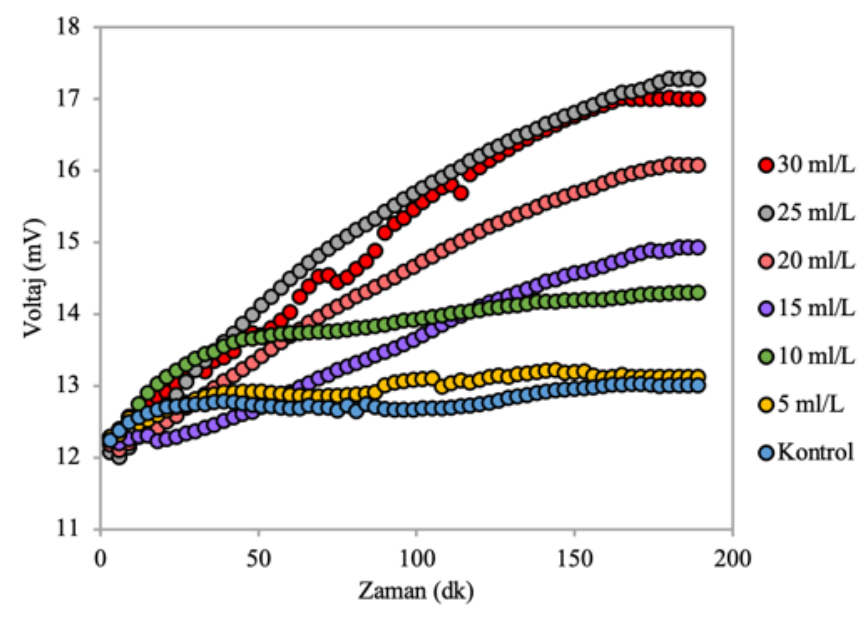

Şekil 2. Voltaj üretimi

Ön işlem uygulaması yapılmamış alg biyokütlesi için MYH-K'da üretilen voltaj değerleri 190 dk'llk süreç boyunca ciddi bir değişime uğramamış ve $12.93 \mathrm{mV}$ düzeylerinde gerçekleşmiştir. $5 \mathrm{ml} / \mathrm{L}$ konsantrasyonda $\mathrm{H}_{2} \mathrm{O}_{2}$ ön işlemi uygulandığ ${ }_{1}$ alg biyokütlesinin $\mathrm{MYH}-\mathrm{A}$ reaktörüne enjeksiyonu sonucunda üretilen voltaj miktarı kontrol reaktörüne kıyasla az miktarda bir artış göstererek $13.2 \mathrm{mV}$ değerlerinde seyretmiştir. $\mathrm{H}_{2} \mathrm{O}_{2}$ konsantrasyonu 10 mL/L'ye yükseltildiğinde, $190 \mathrm{dk}$ 'lık işletme süresi sonunda MYH'de üretilen voltaj $14.28 \mathrm{mV}$ değerine ulaşmıştır. Alg biyokütlesine uygulanan $\mathrm{H}_{2} \mathrm{O}_{2}$ konsantrasyonun 15, 20 ve $25 \mathrm{ml} / \mathrm{L}$ 'ye yükseltilmesi sonucunda MYH'de üretilen voltaj değerleri sırası ile $14.88 \mathrm{mV}, 16.03 \mathrm{mV}$, ve $17.29 \mathrm{mV}$ değerlerine yükselmiştir. $\mathrm{H}_{2} \mathrm{O}_{2}$ konsantrasyonunun $25 \mathrm{ml} / \mathrm{L}$ 'den $30 \mathrm{ml} / \mathrm{L}$ değerine yükseltilmesi ile MYH'nin voltaj üretimi $17.00 \mathrm{mV}$ değerine düşmüştür. Voltaj sonuçları $\mathrm{H}_{2} \mathrm{O}_{2}$ konsantrasyonunun $30 \mathrm{ml} / \mathrm{L}$ değerine arttırılması ile alg biyokütlesinin oksidasyonunun hızlanarak organik parçalanmanın gerçekleşerek organik içerikte azalma olabileceği göstermektedir. Voltaj değerleri incelendiğinde $\mathrm{H}_{2} \mathrm{O}_{2}$ ön işleminin voltaj üretimine ciddi oranda katkı sağladığı ve $25 \mathrm{ml} / \mathrm{L} \mathrm{H}_{2} \mathrm{O}_{2}$ konsantrasyonunun voltaj üretimi açısından optimum değer olduğu tespit edilmiştir. 
Voltaj üretim sonuçları, $\mathrm{H}_{2} \mathrm{O}_{2}$ ön işlemi uygulanması neticesinde alg hücre duvarı parçalanarak dezentegrasyon işleminin gerçekleştĭgi ve bununla beraber alg biyokütlesinin anot bakterileri tarafindan biyolojik ayrıştırılabilirliğinin arttığı kanıtlamıştır. Literatürde ön işlem uygulaması olarak $\mathrm{H}_{2} \mathrm{O}_{2}$ 'nin kullanıldığ çalışmalar incelendiğinde, $\mathrm{H}_{2} \mathrm{O}_{2}$ 'nin kompleks organik bileşiklerin kısmi parçalanmasını gerçekleştirdiği ve buna bağlı olarak arıtım sürecini hızlandırdığı, ve maliyet açısından da oldukça avantajlı bir oksidant olduğu belirtilmiştir [29]. Kumar ve ark. [15] tarafından yapılan çalışmada, $\mathrm{H}_{2} \mathrm{O}_{2}$ ve mikrodalga ön işlem uygulamalarının (15 dk) alg biyokütlesine uygulanması ile biyohidrojen üretiminin \%33.9 arttığı rapor edilmiştir. Diğer taraftan, lignoselülozik yapıdaki biyokütlelerden biyo-yakıt üretimi üzerine yapılan çalışmalar incelendiğinde, enerji tüketimi ve maliyet göz ardı edildiği takdirde ön işlem yaklaşımının sistem performansını ciddi oranda arttırdığı ve gerekliliği araştırmacılar tarafindan rapor edilmiştir [30,31].

\subsubsection{Güc üretimi}

MYH sistemlerinde üretilen güç yoğunluğu, MYH performansını gösteren en önemli parametrelerden biridir. MYH reaktörüne alg biyokütlesinin enjekte edilmesi ile voltaj üretiminde meydana gelen artışın ardından yaklaşık olarak $180 \mathrm{dk}$ 'lık süre sonunda sabitlenme gözlenmiştir. Voltaj üretiminin sabitlendiği süreçte MYH'de güç analizi yapılmıştır. Buna karșın, ham alg biyokütlesi ile MYH-K reaktöründe üretilen güç yoğunluğunun $41.16 \mathrm{~mW} / \mathrm{m}^{2}$ olduğu tespit edilmiştir (Şekil 3).

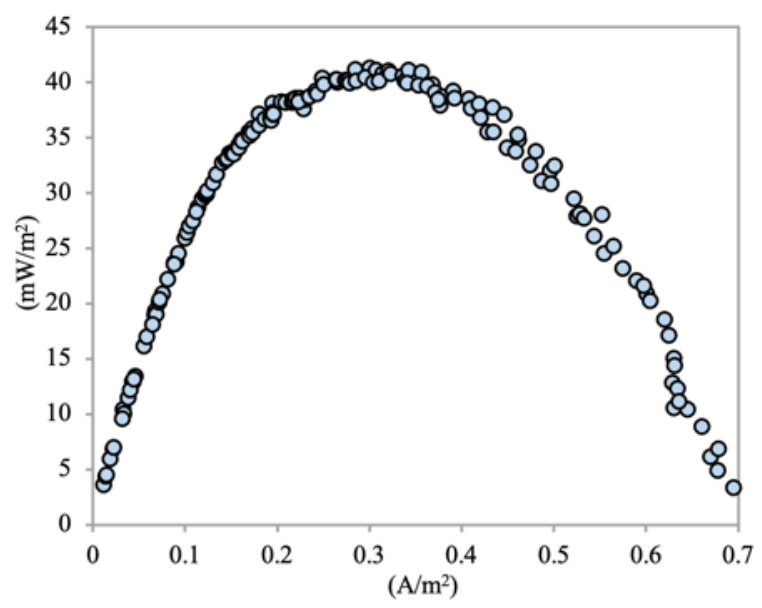

Şekil 3. MYH-K reaktörüne ait güç eğrisi

Farklı konsantrasyonlarda $\mathrm{H}_{2} \mathrm{O}_{2}$ ön işlemi uygulanan alg biyokütleleri ile elde edilen güç yoğunlukları Şekil 4'te verilmiştir. Karışık alg biyokütlesine $5 \mathrm{ml} / \mathrm{L}$ konsantrasyonunda $\mathrm{H}_{2} \mathrm{O}_{2}$ ön işlemi uygulanması ile $\mathrm{MYH}-\mathrm{A}$ 'da üretilen güç yoğunluğu yaklaşık $178.57 \mathrm{~mW} / \mathrm{m}^{2}$ olarak elde edilmiş olup kontrol reaktöründe elde edilen güç yoğunluğuna kıyasla 4.3 kat yüksek olarak elde edilmiştir. $\mathrm{H}_{2} \mathrm{O}_{2}$ konsantrasyonunun $10 \mathrm{ml} / \mathrm{L}$ 'ye yükseltilmesi ile MYH-A’nın güç üretimi kontrol reaktörüne kıyasla 4.6 kat artarak $190.8 \mathrm{~mW} / \mathrm{m}^{2}$ değerine yükselmiştir. 

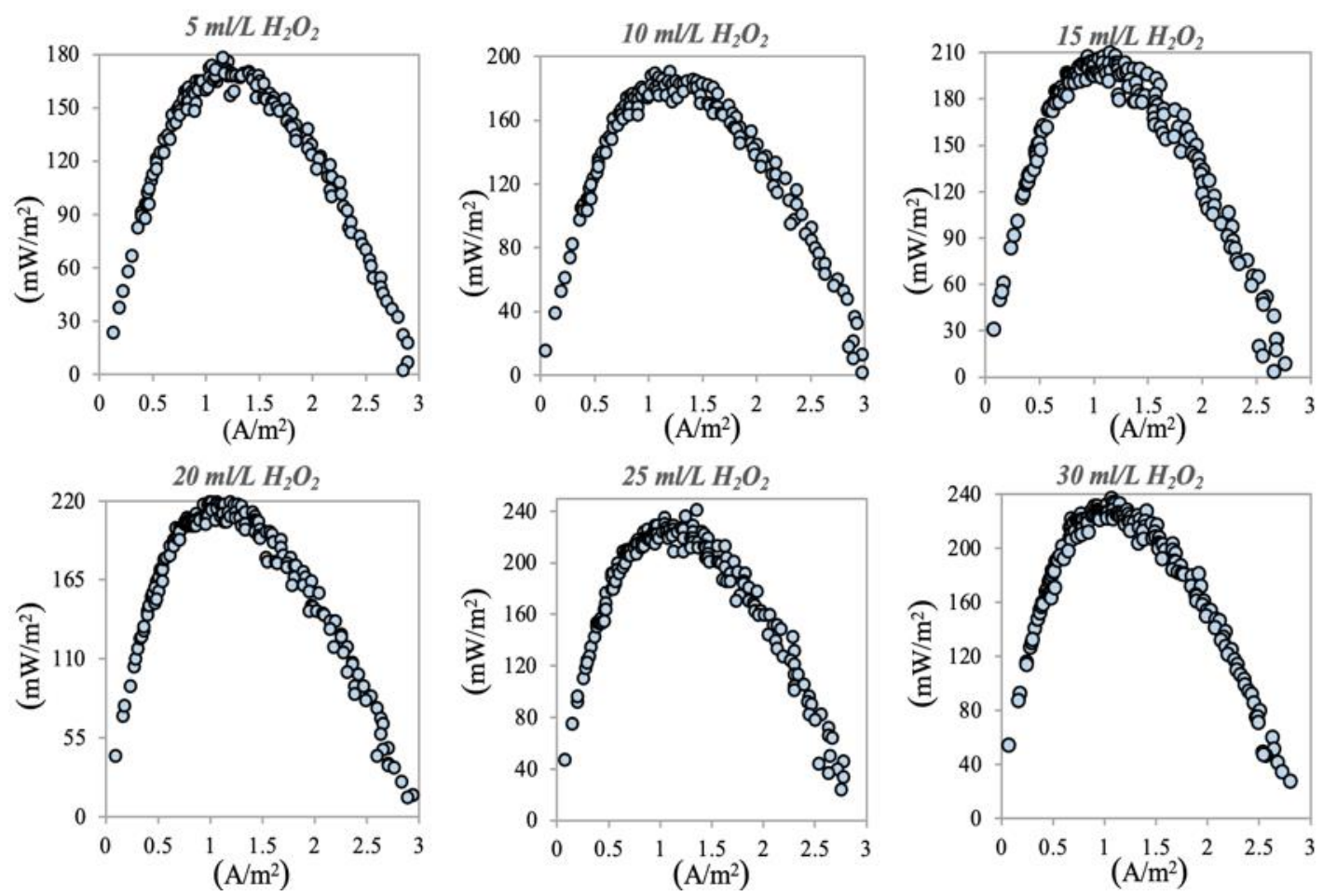

Şekil 4. Farklı $\mathrm{H}_{2} \mathrm{O}_{2}$ konsantrasyonlarının uygulandığı alg biyokütlesi ile elde edilen güç eğrileri

$15,20,25$ ve $30 \mathrm{ml} / \mathrm{L} \mathrm{H}_{2} \mathrm{O}_{2}$ konsantrasyonu uygulanan alg biyokütlelerinin maksimum güç üretimi sırası ile 209.8, 227.64, 244.64 ve $233.54 \mathrm{~mW} / \mathrm{m}^{2}$ olarak elde edilmiştir. Çalışmada en yüksek güç yoğunluğu (244.64 $\left.\mathrm{mW} / \mathrm{m}^{2}\right) 25 \mathrm{ml} / \mathrm{L}$ konsantrasyonunda $\mathrm{H}_{2} \mathrm{O}_{2}$ 'nin uygulandığı alg biyokütlesi ile elde edilmiştir. Bu değer kontrol biyokütlesi ile elde edilen güç yoğunluğuna kıyasla yaklaşık olarak 6 kat daha yüksektir. Literatürde Song ve ark. [32] tarafından yapılan bir çalışmada pirinç samanına sülfürik asit $\left(\mathrm{H}_{2} \mathrm{SO}_{4}\right)$, sodyum hidroksit $(\mathrm{NaOH})$ ve $\mathrm{H}_{2} \mathrm{O}_{2}$ kullanılarak ön işlem uygulanmış ve sediment tipi MYH'de substrat kaynağı olarak kullanmışlardır. Elde ettikleri sonuçlarda $\mathrm{NaOH}$ ön işleminin uygulandığı pirinç samanı ile $140 \mathrm{~mW} / \mathrm{m}^{2}$ güç yoğunluğu elde edilmiş olup bu güç değerinin kontrol beslemesine kıyasla 3.6 kat yüksek olduğu rapor edilmiştir. Geng ve ark. [33] tarafindan yapılan çalışmalarda alkali ön işleminin MYH performansını iyileştirerek yüksek voltaj $(0.74 \mathrm{~V})$ ve güç yoğunluğu $(0.65$ $\mathrm{W} / \mathrm{m}^{2}$ ) elde edildiği belirtilmiştir. Shen ve ark. [34] tarafından yapılmış diğer bir çalışmada mandıra gübresine 0 , 300,600 ve $900 \mathrm{~W}$ gücünde ultrasonik ön işlem uygulanmış ve sırası ile $29.9 \mathrm{~mW} / \mathrm{m}^{2}, 56.2 \mathrm{~mW} / \mathrm{m}^{2}, 102 \mathrm{~mW} / \mathrm{m}^{2}$ ve $72.6 \mathrm{~mW} / \mathrm{m}^{2}$ güç yoğunlukları elde edilmiştir. Elde edilen çalışma sonuçları ve literatür çalışmaları dikkate alındığında ön işlem uygulamasının MYH performansı üzerinde ciddi oranda bir iyileştirme potansiyelinin olduğu görülmektedir.

\subsubsection{CV sonuçları}

$\mathrm{H}_{2} \mathrm{O}_{2}$ ön işleminin MYH'nin anot biyofilminin elektroaktivitesi üzerine etkisini tespit etmek amacı ile MYH'lerde CV analizleri yapılmıştır. MYH-K ve MYH-A reaktörlerde işletme süresi sonunda yapılan CV analiz sonuçları Şekil 5'te verilmiştir. Elde edilen sonuçlar MYH-A reaktöre ait CV analizi için elde edilen akım yoğunluğunun MYH-K reaktörüne kıyasla oldukça yüksek olduğunu göstermiştir. MYH-K reaktörü için elde edilen maksimum akım yoğunluğu $0.052 \mathrm{~A} / \mathrm{m}^{2}$ iken MYH-A reaktöründe elde edilen akım yoğunluğu $2.3 \mathrm{~A} / \mathrm{m}^{2}$ olarak elde edilmiştir. 

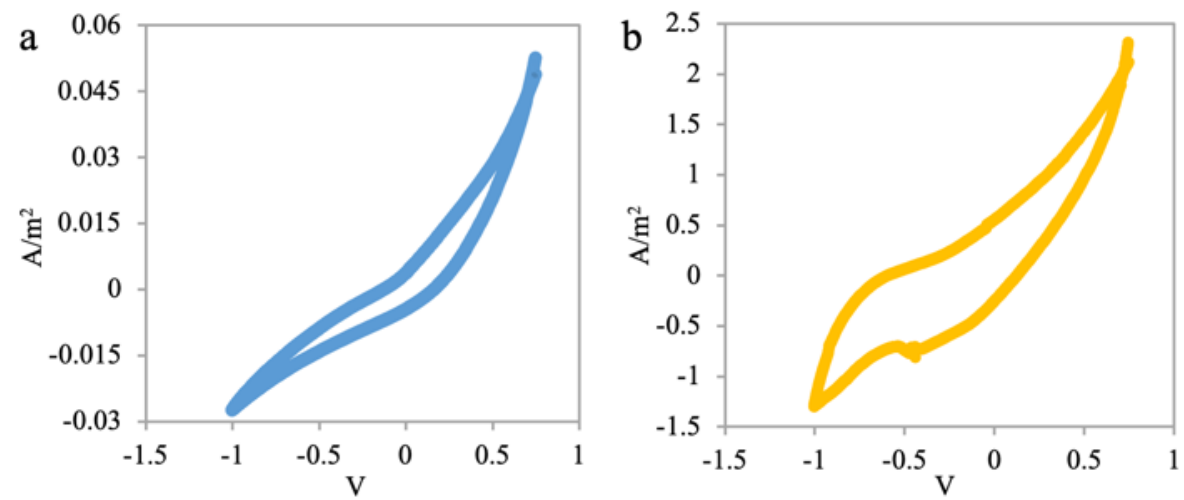

Şekil 5. MYH reaktörlerinin CV sonuçları (A: MYH-K, B: MYH-A)

Elde edilen sonuçlar MYH-A reaktörünün hem katodik hem de anodik akımının yüksek olması uygulanan ön işlemin MYH performansı üzerindeki olumlu etkisini göstermektedir. Ön işlem uygulaması alg biyokütlesinin anot mikroorganizmaları tarafından ayrıştırılmasını kolaylaştırarak anot elektrotu yüzeyinde bakteriyel çoğalmayı hızlandırmıştır. Buna bağlı olarak MYH-A'da anot biyofilm oluşumu desteklemiş ve elektroaktif bir biyofilm yapısı sağlanarak elektron transferi hızlanmıştır. Bununla birlikte alg biyokütlesinin kolay parçalanabilir organik içeriği MYH'nin akım üretimini de arttırdığ 1 kanıtlanmıştır. Sonuç olarak $\mathrm{CV}$ verileri, $\mathrm{H}_{2} \mathrm{O}_{2}$ ön işlem uygulamasının alg biyokütlesinin $\mathrm{MYH}$ reaktöründe elektron transfer mekanizmalarını hızlandırdığını göstermiştir.

\subsection{Mikrobiyal analiz sonuçları}

$\mathrm{H}_{2} \mathrm{O}_{2}$ ön işlem uygulamasının MYH'lerin anot biyofilminde mikrobiyal komunite üzerindeki etkisini tespit etmek amacı ile işletme süresi sonunda reaktörlerden anot biyofilm numuneleri alınmış ve PCR-DGGE analizleri uygulanmıştır. DGGE analizi sonucunda MYH'lerde toplamda 22 adet bakteriyel türün varlığı tespit edilmiştir. MYH-K ve MYH-A reaktörlerinin anot biyofilmlerinde tespit edilen bakterilere ait bantlar ve tür isimleri Şekil 6'da verilmiştir.

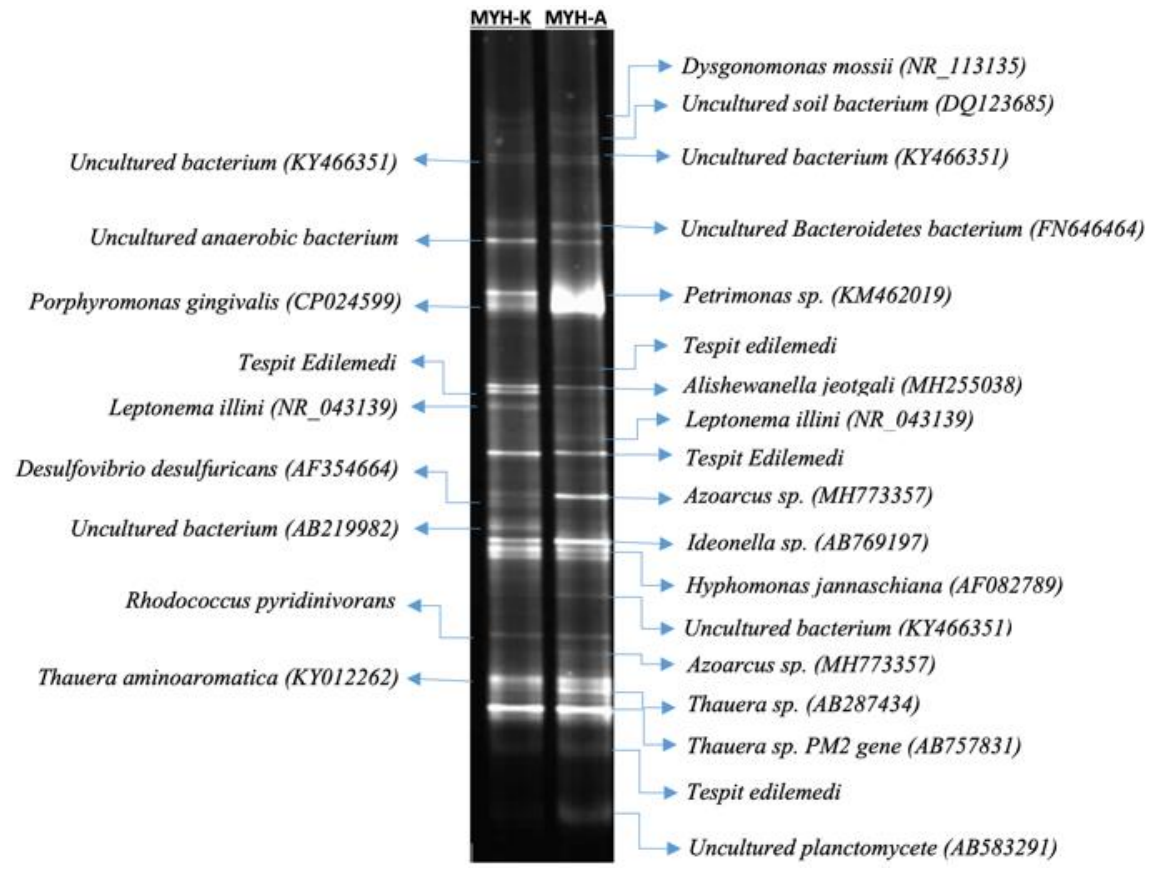

Şekil 6. MYH reaktörlerinden alınan biyofilm numunelerine ait DGGE jel görüntüsü 
DGGE jel görüntüsü $\mathrm{H}_{2} \mathrm{O}_{2}$ ön işleminin MYH'lerin anot biyofilminde ortak türlerin yanı sıra farklı türlerin de baskın olduğunu göstermektedir. Leptonema illini (NR_043139) ve Azoarcus sp. (MH773357) gibi türler MYHA reaktöründe tespit edilirken $\mathrm{MYH}-\mathrm{K}$ reaktörünün anot biyofilminde tespit edilememiştir. Ayrıca tespit edilen bant yoğunlukları Uncultured Bacteroidetes bacterium (FN646464), Petrimonas sp. (KM462019), Alishewanella jeotgali (MH255038) ve Azoarcus sp. (MH773357) gibi türlerin yoğunluğunun MYH-K ve MYH-A reaktörlerinde farklı olduğunu göstermiştir. Meydana gelen farklılık, alg biyokütlesine yapılan $\mathrm{H}_{2} \mathrm{O}_{2}$ ön işleminin mikrobiyal komuniteyi etkilemesi ile açıklanabilir. MYH-K ve MYH-A reaktörlerinde sırasıyla 17 ve 19 türün baskın olduğu görülmüştür. MYH reaktörlerinde tespit edilen bakteriyel türler literatürde yapılmış MYH çalışmalarda da rapor edilmiştir. MYH-A reaktörünün anot biyofilminde tespit edilen Azoarcus sp. türü alkol kullanılarak elektrik üretimi yapılmış çift bölmeli bir MYH reaktörünün anot biyofilminde \%17.4 oranında tespit edilmiş ve $488 \pm 12$ $\mathrm{mW} / \mathrm{m}^{2}$ güç yoğunluğu rapor edilmiştir [35]. MYH-A reaktöründe tespit edilen diğer bir tür olan Dysgonomonas mossii Li ve ark. [36] tarafından izole edilerek MYH sisteminde elektrik üretim potansiyeli araştırılmış ve 104.3 $\mathrm{mW} / \mathrm{m}^{2}$ güç yoğunluğu rapor edilmiştir. Daha önce yapılmış MYH çalışmalarında Thauera sp. türü çikolata endüstrisi atıksularının arıtımının ve eş zamanlı elektrik üretiminin araştırıldığı aktif çamur tabanlı MYH sisteminde tespit edilmiştir [37].

MYH-K ve MYH-A reaktörlerinde tespit edilen baskın türlerin ait oldukları bakteri sınıfları Şekil 7'de verilmiştir. Anot biyofilmlerinde $\mathrm{H}_{2} \mathrm{O}_{2}$ ön işlemi sonrası en yüksek oranda bulunan bakteri sınıfları Environmental samples ve $b$-proteobacteria grubuna aittir bakterilerdir.
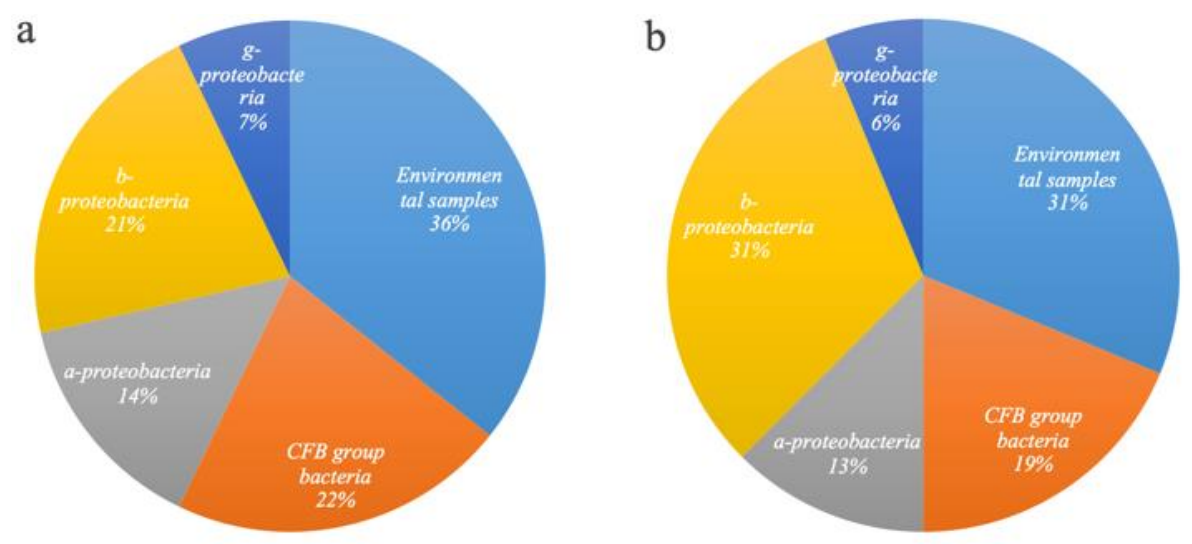

Şekil 7. MYH reaktörlerindeki baskın tür sınıfları (a: MYH-K ve b: MYH-A)

Elde edilen DGGE sonuçlarına göre MYH-K reaktöründe ve MYH-A reaktörlerinde mikroorganizma sınıflarının büyük bir kısmının Environmental samples grubundaki bakteriyel türler olduğu tespit edilmiştir. Environmental samples sınıfindan sonra MYH'lerde en yaygın rastlanan bakteri sinıfi b-proteobacteria'dır. Bu sınıfa ait bakteriler MYH-K ve MYH-A reaktörlerinin anot biyofilmlerinde sırası ile \%21 ve \%31 oranında tespit edilmiştir. Daha önceki çalışmalarda, bu sınıfa ait bakteriler MYH sistemlerinde çok yaygın bir şekilde tespit edilmektedir. Li ve ark. [38] tarafından yapılan bir çalışmada, b-proteobacteria sınıfına ait bakteri türlerinin sediment tipi MYH'de baskın türler olduğu rapor edilmiştir. Diğer bir çalışmada, Zhao ve Kong [39] MYH anot biyofilm komunitesinin \%47.61 oranında b-proteobacteria sınıfına ait bakteriler içerdiğini rapor etmiştir. Kim ve ark. [40] b-proteobacteria ve g-proteobacteria sınıfına ait bakterilerin elektroaktif türler olduğunu ve iletken biyofilm tabakası oluşturabildiğini rapor etmişlerdir. Ayrıca b-proteobacteria sınıfına ait bakterilerin organik maddelerin ayrıştırılmasından ve elektrik üretiminden sorumlu olduğu tespit edilmiştir [41]. Anot biyofilminde tespit edilen diğer bir bakteri sınıfı ise g-proteobacteria'dır. Bu bakteriyel sınıf MYH-K ve MYH-A reaktörlerinde sırası ile $\% 7$ ve $\% 6$ oranında tespit edilmiştir. Wu ve ark. [42] g-proteobacteria sınıfina ait olan bakterilerin hücre dışı elektron transferi yapabilme yeteneğine sahip olduğunu ve bunun sonucunda MYH sisteminde yüksek güç yoğunluklarına ulaşılabildiğini rapor etmiştir. Sonuç olarak $\mathrm{H}_{2} \mathrm{O}_{2}$ ön işlem uygulaması belirgin bir şekilde $b$ proteobacteria sınıfına ait bakteriyel türlerin çoğalmasını desteklemiş ve bu sınıfa ait türler MYH-A'nın elektrik üretimine katkıda bulunmuştur. Ayrıca hücre dişı elektron transferi yapabilme yeteneğine sahip olan bakteriyel türleri içeren g-proteobacteria sınıfına ait bakteri türlerinin de varlığı tespit edilmiştir. 


\section{Sonuçlar}

$\mathrm{Bu}$ çalışmada karışık alg biyokütlesine farklı konsantrasyonlarda $\mathrm{H}_{2} \mathrm{O}_{2}$ ön işlemi uygulanarak MYH'de anot bölmesinde substrat kaynağı olarak kullanılmış ve ön işlemin MYH performansına katkısı araştırılmıştır. MYH'lerin güç üretimi incelendiğinde, en yüksek performans artış $25 \mathrm{ml} / \mathrm{L} \mathrm{H}_{2} \mathrm{O}_{2}$ konsantrasyonunun uygulandığı alg biyokütlesi ile $244.64 \mathrm{~mW} / \mathrm{m}^{2}$ olarak elde edilmiştir. Bu değer $\mathrm{MYH}-\mathrm{K}$ reaktöründe elde edilen güç değerinden $\left(41.16 \mathrm{~mW} / \mathrm{m}^{2}\right) 6$ kat daha yüksektir. CV sonuçları, MYH-A'nın anot biyofilminin elektroaktivitesinin MYH-K reaktörünün anot biyofilmine kıyasla daha yüksek olduğunu göstermiştir. Moleküler analizler $\mathrm{H}_{2} \mathrm{O}_{2}$ ön işleminin anot biyofilm elektroaktif mikrobiyal türlerin varlığını desteklediğini ve bu durumun MYH'nin elektrik üretimine katk1 sağladığını göstermiştir. Sonuç olarak $\mathrm{H}_{2} \mathrm{O}_{2}$ ön işlemi $\mathrm{MYH}$ 'nin güç üretimini ciddi oranda arttırmış olup MYH'lerde kullanılan zor ayrışabilir besi maddeleri için önemli bir uygulama potansiyeline sahiptir.

Teșekkür: Bu çalışma, "Farklı Ön İşlem Teknikleri Uygulanmış Alg Biyokütlesinin Mikrobiyal Yakıt Hücresinde Elektrik Üretim Performansının Araştııılması" başlıklı yüksek lisans çalışmasının bir kısmını içermektedir. M.F.H. deneysel düzeneğin hazırlanması, analizlerin yapılması, sonuçların yorumlanması ve makalenin yazılmasına katkıda bulundu. E.T. fikir sahibi, deneysel düzeneğin hazırlanması, sonuçların yorumlanmasına ve makalenin yazılmasına katkıda bulundu.

\section{Kaynaklar}

[1] Love BJ, Einheuser MD, Nejadhashemi AP. Effects on aquatic and human health due to large scale bioenergy crop expansion. Sci Total Environ 2011; 409: 3215-3229.

[2] Feng Y, Harper Jr WF. Biosensing with microbial fuel cells and artificial neural networks: laboratory and field investigations. J Environ Manage 2013; 130: 369-374.

[3] Sinyak Y. Global climate and energy systems. Sci Total Environ 1994; 143: 31-51.

[4] Zhou M, Chi M, Wang H, Jin T. Anode modification by electrochemical oxidation: A new practical method to improve the performance of microbial fuel cells. Biochem Eng J 2012; 60: 151-155.

[5] Wen Q, Kong F, Zheng H, Cao D, Ren Y, Yin J. Electricity generation from synthetic penicillin wastewater in an aircathode single chamber microbial fuel cell. Chem Eng J 2011; 168: 572-576.

[6] Rabaey K, Verstraete W. Microbial fuel cells: novel biotechnology for energy generation. Trends Biotechnol 2005; 23 : 291-298.

[7] Reyes KRE, Tsai P-W, Tayo LL, Hsueh C-C, Chen B-Y. Biodegradation of anthraquinone dyes: Interactive assessment upon biodecolorization, biosorption and biotoxicity using dual-chamber microbial fuel cells (MFCs). Process Biochem 2021; 101: 111-127.

[8] Huang S-J, Ubando AT, Wang C-Y, Su Y-X, Culaba AB, Lin Y-A, Wang C-T. Modification of carbon based cathode electrode in a batch-type microbial fuel cells. Biomass Bioenergy 2021; 145: 105972.

[9] Taşkan B. Increased power generation from a new sandwich-type microbial fuel cell (ST-MFC) with a membrane-aerated cathode. Biomass Bioenergy 2020; 142: 105781.

[10] Gupta S, Nayak A, Roy C, Yadav AK. An algal assisted constructed wetland-microbial fuel cell integrated with sand filter for efficient wastewater treatment and electricity production. Chemosphere 2021; 263: 128132.

[11] Blanken W, Postma PR, de Winter L, Wijffels RH, Janssen M. Predicting microalgae growth. Algal Res. 2016; 14: 2838.

[12] Barahoei M, Hatamipour MS, Afsharzadeh S. $\mathrm{CO}_{2}$ capturing by chlorella vulgaris in a bubble column photo-bioreactor; Effect of bubble size on $\mathrm{CO}_{2}$ removal and growth rate. $\mathrm{J} . \mathrm{CO}_{2}$ Util. 2020; 37: 9-19.

[13] Martínez C, Mairet F, Plaza L, Sciandra A, Bernard O. Quantifying the potential of microalgae to remove nutrients from wastewater. IFAC-PapersOnLine 2019; 52: 287-292.

[14] de Carvalho JC, Magalhães Jr AI, de Melo Pereira GV, Medeiros ABP, Sydney EB, Rodrigues C, Aulestia DTM, de Souza Vandenberghe LP, Soccol VT, Soccol CR. Microalgal biomass pretreatment for integrated processing into biofuels, food, and feed. Bioresour. Technol. 2020; 300: 122719.

[15] Kumar MD, Kaliappan S, Gopikumar S, Zhen G, Banu JR. Synergetic pretreatment of algal biomass through H2O2 induced microwave in acidic condition for biohydrogen production. Fuel 2019; 253: 833-839.

[16] Chavoshani A, Amin MM, Asgari G, Seidmohammadi A, Hashemi M. In Advanced Oxidation Processes for Waste Water Treatment. Elsevier, 2018. pp. 215-255.

[17] Teong SP, Li X, Zhang Y. Hydrogen peroxide as an oxidant in biomass-to-chemical processes of industrial interest. Green Chem. 2019; 21: 5753-5780.

[18] Eswari P, Kavitha S, Kaliappan S, Yeom I-T, Banu JR. Enhancement of sludge anaerobic biodegradability by combined microwave- $\mathrm{H}_{2} \mathrm{O}_{2}$ pretreatment in acidic conditions. Environ. Sci. Pollut. Res. 2016; 23: 13467-13479.

[19] Ho MC, Ong VZ, Wu TY. Potential use of alkaline hydrogen peroxide in lignocellulosic biomass pretreatment and valorization - A review. Renewable Sustainable Energy Rev 2019; 112: 75-86. 
[20] Liu J, Yu D, Zhang J, Yang M, Wang Y, Wei Y, Tong J. Rheological properties of sewage sludge during enhanced anaerobic digestion with microwave- $\mathrm{H}_{2} \mathrm{O}_{2}$ pretreatment. Water Res. 2016; 98: 98-108.

[21] Rashid N, Cui Y-F, Saif Ur Rehman M, Han J-I. Enhanced electricity generation by using algae biomass and activated sludge in microbial fuel cell. Sci Total Environ 2013; 456-457: 91-94.

[22] Rashid N, Cui Y-F, Rehman MSU, Han J-I. Enhanced electricity generation by using algae biomass and activated sludge in microbial fuel cell. Sc1 Total Environ 2013; 456: 91-94.

[23] Ashok V, Shriwastav A, Bose P. Nutrient removal using algal-bacterial mixed culture. Appl. Biochem. Biotechnol. 2014; 174: 2827-2838.

[24] Muñoz R, Jacinto M, Guieysse B, Mattiasson B. Combined carbon and nitrogen removal from acetonitrile using algalbacterial bioreactors. Appl. Microbiol. Biotechnol. 2005; 67: 699-707.

[25] Taşkan E, Bulak S, Taşkan B, Şaşmaz M, El Abed S, El Abed A. Nitinol as a suitable anode material for electricity generation in microbial fuel cells. Bioelectrochemistry 2019; 128: 118-125.

[26] Muyzer G, De Waal EC, Uitterlinden AG. Profiling of complex microbial populations by denaturing gradient gel electrophoresis analysis of polymerase chain reaction-amplified genes coding for 16S rRNA. Appl. Environ. Microbiol. 1993; 59: 695-700.

[27] Muyzer G. Denaturing gradient gel electrophoresis of PCR-amplified 16S rDNA. A new molecular approach to analyze the genetic diversity of mixed microbial communities. Molecular microbial ecology manual: Springer, 1996.

[28] Taskan E, Hasar H. Comprehensive comparison of a new tin-coated copper mesh and a graphite plate electrode as an anode material in microbial fuel cell. Appl. Biochem. Biotechnol. 2015; 175: 2300-2308.

[29] Ameta SC, Ameta R. (2018) Advanced oxidation processes for wastewater treatment: emerging green chemical technology. ed. Academic press. Rajasthan, India: Elsevier, 2018.

[30] Monlau F, Barakat A, Trably E, Dumas C, Steyer J-P, Carrère H. Lignocellulosic materials into biohydrogen and biomethane: impact of structural features and pretreatment. Crit Rev Env Sci Tec 2013; 43: 260-322.

[31] Sivagurunathan P, Kumar G, Sen B, Lin CY. Development of a novel hybrid immobilization material (HY-IM) for fermentative biohydrogen production from beverage wastewater. J. Chin. Chem. Soc. 2014; 61: 827-830.

[32] Song T-s, Hou S, Zhang J, Wang H, Xie J. Production of Electricity from Rice Straw with different Pretreatment Methods Using a Sediment Microbial Fuel Cell. Int. J. Electrochem. Sci.2018; 13: 461-471.

[33] Geng Y-K, Yuan L, Liu T, Li Z-H, Zheng X, Sheng G-P. In-situ alkaline pretreatment of waste activated sludge in microbial fuel cell enhanced power production. J. Power Sources 2021; 491: 229616.

[34] Shen J, Wang C, Liu Y, Hu C, Xin Y, Ding N, Su S. Effect of ultrasonic pretreatment of the dairy manure on the electricity generation of microbial fuel cell. Biochem Eng J 2018; 129: 44-49.

[35] Kim JR, Jung SH, Regan JM, Logan BE. Electricity generation and microbial community analysis of alcohol powered microbial fuel cells. Bioresour. Technol. 2007; 98: 2568-2577.

[36] Li Y, Sun Y, Kong X, Li L, Yang G, Yuan Z. Isolation and electricity-producing characteristics of strain Dysgonomonas mossii. Trans. CSAE 2011; 27: 181-184.

[37] Patil SA, Surakasi VP, Koul S, Ijmulwar S, Vivek A, Shouche YS, Kapadnis BP. Electricity generation using chocolate industry wastewater and its treatment in activated sludge based microbial fuel cell and analysis of developed microbial community in the anode chamber. Bioresour. Technol. 2009; 100: 5132-5139.

[38] Li T, Fang Z, Yu R, Cao X, Song H, Li X. The performance of the microbial fuel cell-coupled constructed wetland system and the influence of the anode bacterial community. Environ. Technol. 2016; 37: 1683-1692.

[39] Zhao H, Kong C-H. Enhanced removal of p-nitrophenol in a microbial fuel cell after long-term operation and the catabolic versatility of its microbial community. Chem Eng J 2018; 339: 424-431.

[40] Kim G, Webster G, Wimpenny J, Kim BH, Kim H, Weightman AJ. Bacterial community structure, compartmentalization and activity in a microbial fuel cell. J. Appl. Microbiol. 2006; 101: 698-710.

[41] Kumar SS, Malyan SK, Basu S, Bishnoi NR. Syntrophic association and performance of Clostridium, Desulfovibrio, Aeromonas and Tetrathiobacter as anodic biocatalysts for bioelectricity generation in dual chamber microbial fuel cell. Environ. Sci. Pollut. Res. 2017; 24: 16019-16030.

[42] Wu X, Xiong X, Owens G, Brunetti G, Zhou J, Yong X, Xie X, Zhang L, Wei P, Jia H. Anode modification by biogenic gold nanoparticles for the improved performance of microbial fuel cells and microbial community shift. Bioresour. Technol. 2018; 270: 11-19. 